\title{
Cerebellar hypoplasia in a case with neurofibromatosis type 1
}

\author{
Sedat Işıkay
}

Department of Pediatric Neurology, Gaziantep Children's Hospital, Gaziantep, Turkey

\section{Correspondence to}

Dr Sedat Işıkay,

dr.sedatisikay@mynet.com

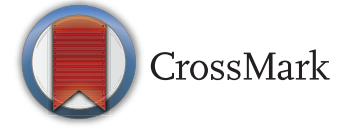

To cite: Işıkay S. BMJ Case Rep Published online:

[please include Day Month Year] doi:10.1136/bcr-2013202160

\section{DESCRIPTION}

A 6-year-old boy was followed by our clinic due to epilepsy and neurofibromatosis type 1 (NF-1). The patient experienced generalised tonic-clonic seizures for the previous 3 years, which were controlled by 1.5 years of valproic aci and clonazepam treatments. Physical examination found many café-au-lait spots on various parts of the body and Lisch nodules in the iris on eye examination. Neurological examination showed cerebellar dysfunctions (gait ataxia, dysmetria, dysdiadochokinesia and dysarthria) and mild mental retardation.
Brain MRI showed global cerebellar hypoplasia and signal variations in bilateral thalamuses. Subarachnoid distance was found to be large in posterior fossa (figure 1).

NF-1 is an autosomal dominant neurocutaneous syndrome with frequent involvement of the central nervous system. Evaluation of the central nervous system in NF-1 may help identify heterotopia, cortical dysplasia, cortical malformations such as pachygyria and polymicrogyria, unidentified bright objects, optic glioma, encephalocele, Arnold-Chiari malformation and aqueductal stenosis. ${ }^{1}$ Cerebellar

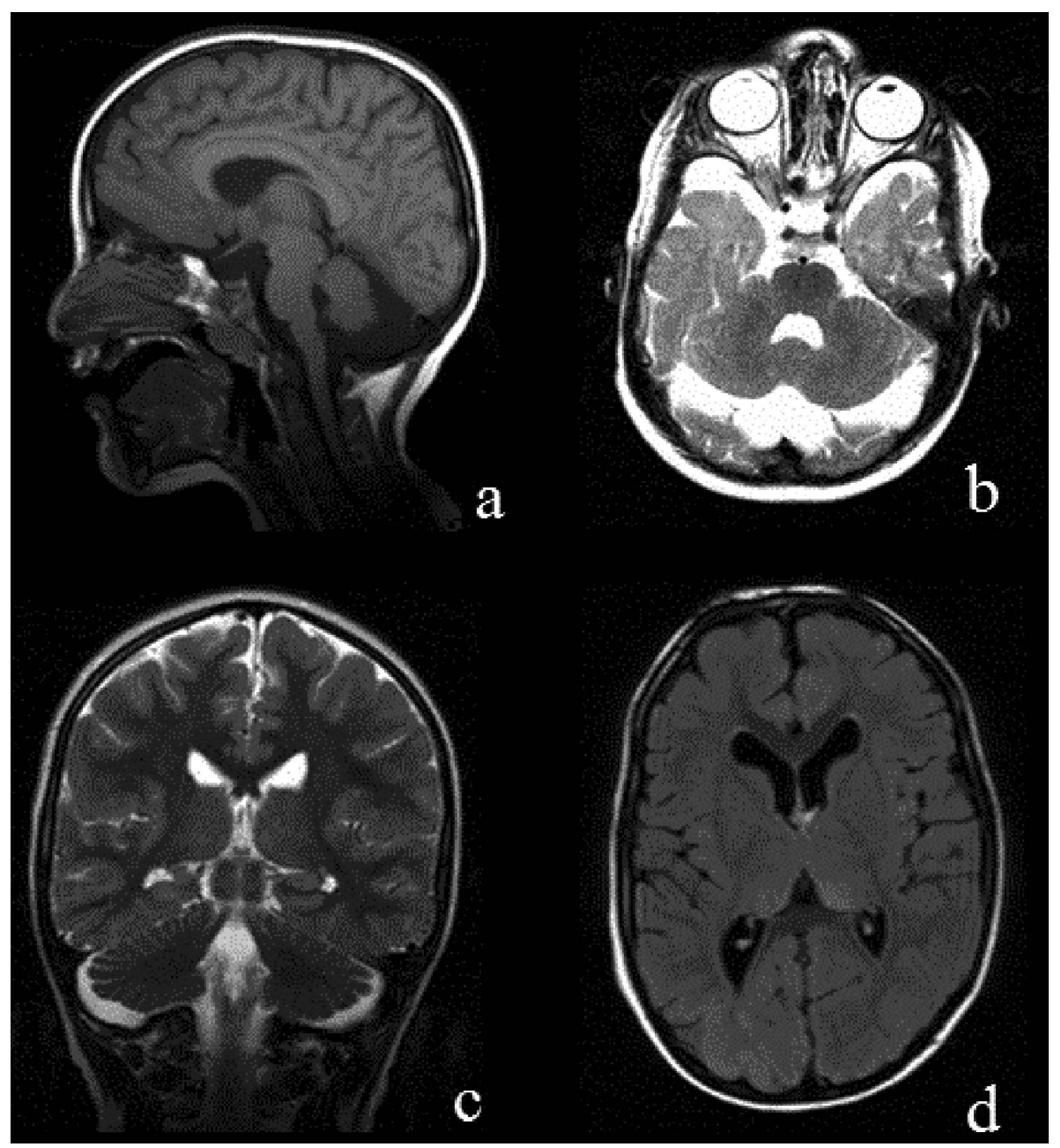

Figure 1 Images of T1-weighted sagittal (A), T2-weighted axial (B) and coronal (C) cross-sections of cerebellar hypoplasia and subarachnoid distance in posterior fossa of the patient. Image of hyperintensity in bilateral thalamuses in T2-weighted fluid-attenuated inversion recovery cross-section (D). 


\section{Learning points}

- NF-1 is an autosomal dominant neurocutaneous syndrome with frequent involvement of the central nervous system.

- Cerebellar hypoplasia is very rare in neurofibromatosis type 1 (NF-1).

- In patients with NF-1 with cerebellar findings, central imaging should be used to detect potential congenital and acquired pathologies.

hypoplasia is very rare in NF-1. ${ }^{2}$ In cerebellar hypoplasia, typically, the vermis is more severely affected than the hemispheres because the vermis is the last part of the cerebellum to form. ${ }^{3}$
The subarachnoid spaces we detected in our patient may be passively enlarged. ${ }^{1-3}$ The patient has areas of hyperintensity in thalamuses, consistent with unidentified bright objects and global cerebellar hypoplasia. In conclusion, cerebellar hypoplasia is rarely observed in cases diagnosed as NF-1.

Competing interests None.

Patient consent Obtained.

Provenance and peer review Not commissioned; externally peer reviewed.

\section{REFERENCES}

1 DiMario FJ Jr, Ramsby G. Magnetic resonance imaging lesion analysis in neurofibromatosis type 1. Arch Neurol 1998;55:500-5.

2 Al-Hail H, Ruiz-Miyares F, Deleu D, et al. Cerebellar hypoplasia and vertebral indentations in a case of neurofibromatosis type I. Rev Neurol 2008;46:626-7.

3 Benbir G, Kara S, Yalcinkaya BC, et al. Unilateral cerebellar hypoplasia with different clinical features. Cerebellum 2011;10:49-60.

Copyright 2013 BMJ Publishing Group. All rights reserved. For permission to reuse any of this content visit

http://group.bmj.com/group/rights-licensing/permissions.

BMJ Case Report Fellows may re-use this article for personal use and teaching without any further permission.

Become a Fellow of BMJ Case Reports today and you can:

- Submit as many cases as you like

- Enjoy fast sympathetic peer review and rapid publication of accepted articles

- Access all the published articles

- Re-use any of the published material for personal use and teaching without further permission

For information on Institutional Fellowships contact consortiasales@bmjgroup.com

Visit casereports.bmj.com for more articles like this and to become a Fellow 